\title{
Effect of Age and Breeds of Cattle on Carcass and Meat Characteristics of Arsi, Boran, and Harar Cattle in Ethiopia
}

\author{
Timketa Dagne Tefera1, Yesihak Yusuf Mummed², Mohammed Yusuf Kurtu², \\ Mengistu Urge Letta' ${ }^{2}$, Travis G. 0'Quine ${ }^{3}$, Jessie L. Vipham ${ }^{3}$
}

${ }^{1}$ Department of Animal Science, College of Agriculture, Oda Bultum University, Chiro, Ethiopia

${ }^{2}$ School of Animal and Range Sciences, College of Agriculture and Environmental Sciences, Haramaya University, Dire Dawa, Ethiopia ${ }^{3}$ Department of Animal Sciences and Industry, Kansas State University, Manhattan, USA

Email: timketadagne@gmail.com

How to cite this paper: Tefera, T.D., Mummed, Y.Y., Kurtu, M.Y., Letta, M.U., O'Quine, T.G. and Vipham, J.L. (2019) Effect of Age and Breeds of Cattle on Carcass and Meat Characteristics of Arsi, Boran, and Harar Cattle in Ethiopia. Open Journal of Animal Sciences, 9, 367-383. https://doi.org/10.4236/ojas.2019.93030

Received: May 24, 2019

Accepted: July 28, 2019

Published: July 31, 2019

Copyright $\odot 2019$ by author(s) and Scientific Research Publishing Inc. This work is licensed under the Creative Commons Attribution International License (CC BY 4.0).

http://creativecommons.org/licenses/by/4.0/

\begin{abstract}
The objective of this study was to determine the effect of age and breed of cattle on carcass and meat characteristics in Ethiopia. A total of 39 (Arsi 11, Boran 14 and Harar 14) cattle breeds with age categories of $<3,4-6$, and 7 - 9 years were used for the study. The bulls were purchased from their respective production system of mixed crop livestock system (Arsi and Harar) and Ranch (Boran). Parameters such as live and carcass weight, meat yield percent, fat characteristics, and primal beef cuts were evaluated. Complete randomized design was used for the study. The live weight of bulls at $<3,4-6$ and 7 - 9 years ranged $135-183,167-181$, and $155-433 \mathrm{~kg}$, respectively. The carcass weight, dressing percentage, meat yield percent, forequarter, hindquarter, rib eye area, and fat thickness ranged $57-209.73 \mathrm{~kg}, 41.8 \%-51.6 \%$, $32 \%-58 \%, 11.7-56.42 \mathrm{~kg}, 14.04-45.34 \mathrm{~kg}, 4.78-10.25$ square inches and $0.18-0.38$ inches, respectively. At an early age category ( $<3$ years) meat yield percentage of Arsi, Boran and Harar breeds were 50.86, 30 and 18.72, respectively, and as age category shifted from one age category to the next Harar increased by $13 \times$ and Boran by $2.9 \times$ and Arsi decreased by $-0.93 \times$. The mean rib percentage of Arsi, Boran and Harar were in the range of 7.98 - 9.57, $8.62-10.44$ and $7.08-8.83$, respectively. Breed and age of bulls had significantly affected primal meat cuts. Meat yield was predicted from live and hot carcass weight with coefficient determination $\left(\mathrm{R}^{2}\right)$ of $70.66 \%$ and $74.75 \%$, respectively. From the study, it was concluded that age and breeds of cattle had significantly influence on carcass and meat characteristics. Therefore, to determine whether variations were due to genetic or environmental cause's evaluation of the three breeds under similar feeding condition was recommended.
\end{abstract}




\section{Keywords}

Breed, Age, Carcass, Meat Yield Percent, Fat Characteristics

\section{Introduction}

Ethiopia has the largest livestock population in Africa and possesses 60.39 million heads of cattle, 31.30 million sheep, 32.74 million goats, and 60.04 million poultry [1]. The sector contributes $15 \%$ - $17 \%$ of the country's gross domestic product (GDP), 35\% - 40\% of agricultural GDP and 37\% - 87\% of the household incomes [2]. However, the country is not fully exploiting this large resource and productivity of the animal is low and products being produced are of low quality [3] [4]. Cattle production is one of the main animal's agriculture in Ethiopia [5]. In Ethiopia, there were 25 indigenous cattle breeds were identified [6] [7]. These breed contrasts were credited to differences in carcass weight and/or fatness [8] [9]. Age of an animal additionally a significant factor in deciding the delicacy and adequacy of meat [10].

Beef is one of the widely consumed protein sources in the world. The average carcass weight per cattle for Ethiopian was $135 \mathrm{~kg}$, which was by far less than the average of $146 \mathrm{~kg}$ for Africa, and $205 \mathrm{~kg}$ for the whole world [11] [12]. Ethiopians consumed about $8 \mathrm{~kg}$ of meat per capita annually, which was less than what was consumed in developing countries [11]. [13], reported the absence of continuous documented information on carcass yield traits of cattle slaughtered at abattoirs in different times in Ethiopia. The review conducted by [14] revealed that there was little information on meat cut yields, quality, and sensory characteristics on indigenous cattle breeds in Ethiopia. Research on meat and meat products were given little attention in the country [15].

A part of the carcass from which primal cut is made is a good indicator of the relative tenderness of a cut and can help consumers decide which method of cookery to use in preparing a cut [16]. Meat cuts differ in their commercial value because of their differences in tenderness and proportion of leanness. The three most important areas that require emphasis in the future research are lean meat yield, eating qualities, and nutritive value of the products [17]. Furthermore, [18] noted that optimization of cattle production requires knowledge of the variation in meat quality and carcass traits and the association between them. There was limited information on the effects of age and breed on beef carcass and meat characteristics in Ethiopian. The objective of this study was to determine the effect of age and breed (Arsi, Boran, and Harar) of cattle on carcass and meat characteristics in Ethiopia.

\section{Materials and Methods}

\subsection{Study Areas}

The study was conducted in West Arsi (kofelle), Borena (Yabello), and West 
Hararge (Chiro), Ethiopia. Kofelle of West Arsi zone is located at $7 \AA 00 \mathrm{~N}$ latitude and $38 \AA 245 \mathrm{E}$ longitude. West Hararge zone is located at $8^{\circ} 40^{\prime} 0^{\prime \prime} \mathrm{N}, 40^{\circ} 30^{\prime} 0^{\prime \prime} \mathrm{E}$ and altitude between 970 and 1410 meter above sea level. The annual rainfall ranges $650 \mathrm{~mm}-950 \mathrm{~mm}$ and means temperature range $17.5^{\circ} \mathrm{C}-27^{\circ} \mathrm{C}$. Mixed crop livestock production is practiced in Arsi and Hareghe regions. Grazing and crop residue are the major feed resource in these regions. Borana zone is semi-arid with an average rainfall ranging 300 to $600 \mathrm{~mm}$ and average daily temperature $19^{\circ} \mathrm{C}$ to $260^{\circ} \mathrm{C}$. Yabelle of Boranzone is located at $4^{\circ} 53^{\prime} \mathrm{N}$ latitude and of $38^{\circ} 5^{\prime} \mathrm{E}$ longitude. Extensive grazing on natural pasture dominated by perennial grasses is practiced in these areas Cenchrus, Pennisetum, and Chrysopogoies species. The area has a bimodal rainfall distribution with the long rains extending from March to May and short rains from September to November.

\subsection{Sampling Procedures and Experimental Animals}

A total of 39 cattle' samples from three breeds of cattle namely, Harar, Arsi and Boran were used for the study. Samples were purchased from their niche market. Accordingly, Hara and Arsi were purchased from Chiro and Kofale local market, respectively. And Boran was purchased from Yea Balo (Didu Tiyura Ranch). Samples were collected based on age categories. The experimental Animals were grouped into three ( $<3,4-6$ and $7-9$ years) age groups. Ages of the cattle were determined according to [19] and [20] age verification guidelines. After purchased individual bulls were ear tagged and transported by vehicle (Isuzu) to Bishoftu (Elfora Abattoir). In order to avoid the effect of transport on quality of meat, cattle were transported in similar condition and were given rest at lairrage for 5 days before slaughtered.

\subsection{Slaughter Procedures and Evaluation of Carcass and Meat Characteristics}

After lairrage rest pre-mortem examinations and slaughter body weights (SBW) were taken immediately before slaughter. The bulls were slaughtered according to the slaughtering plant procedure. Postmortem examinations were taken by veterinarians at the abattoir. Veterinarians were performed postmortem examinations activities to identify weather the carcass was diseased, influenced with a condition that may display a risk to human wellbeing and remains that might be unpleasant to the buyer. After bleeding, flying of the hide, and removing the viscera, carcasses were sawed in to right and left half. Hot Carcass Weight (HCW) was measured based on weight of full carcass. The carcasses were chilled for 24 hours in temperature range of $0^{\circ} \mathrm{C}-4^{\circ} \mathrm{C}$. The carcass and meat characteristics parameters such as dressing percentage, cold carcass weight, rib eye area, fat thickness, and primal meat cut were assessed at the chilling floor.

At the chilling floor, left side of each carcass were sawed at the $12^{\text {th }}$ and $13^{\text {th }}$ ribs to measure the rib eye area and fat thickness of the longissimus muscle. Rib eye area was measured by placing grid plastic paper (Iowa State University ex- 
tension and outreach) on the cut surface of the rib eye and counting all squares in which lean surrounds a dot as per the guidance described by manufacturer of the plastic grid. The number of squares counted was divided by 10 . The resulting number was the area of the rib eye in square inches [21]. Fat thickness was measured by ruler graduated in millimeters. The dressing percentage was evaluated according to [22].

Dressing Percentage (DP) was calculated as:

$$
\text { Dressing Percentage }=\frac{\text { Hot Carcass Weight }}{\text { Live weight }} \times 100
$$

\section{Forequarter, hindquarter Primal meat cuts measurements}

The meat cuts were evaluated according to [23] cattle meat cut methods. The carcasses of the bulls were cut along a symmetric line through the column vertebral, the sternum and the Symphysis pubica. Accordingly, the beef carcass was first separated into right and left sides. Then after, it was separated into forequarter and hindquarter. The forequarter was the anterior portion of the beef side and separated from the hindquarter between the $12^{\text {th }}$ and $13^{\text {th }}$ rib. The hindquarter was the posterior portion of the carcass side after separation from the forequarter and it contained one last Rib bone. The fore and hindquarter were further cut in to the primal/wholesale cuts and weighed, separately. The weight of primal cuts from right side; chuck, rib, round, loin, brisket, plate flank, and shank were determined by weighting scale. The percentage of each primal cuts were calculated based on weights of primal cuts multiplied by 2 and then divided by total carcass weight and multiplied by 100 . Meat yield percentage was evaluated by dividing meat yield by hot carcass weight multiplied by 100 .

\subsection{Experimental Design}

A factorial arrangement with two factors (age and breed) in the CRD (Completely Randomized Design) was used for the study. The treatment composition was indicated in Table 1.

\subsection{Statistical Analyses}

The data were analyzed by the procedure of General Linear Model (GLM) using SAS software [24]. When the GLM showed the presence of significant difference between the different parameters, the Duncan's multiple range tests were used

Table 1. Treatment composition.

\begin{tabular}{ccccc}
\hline \multirow{2}{*}{ Cattle Breeds } & \multicolumn{3}{c}{ Age (Years) } & \multirow{2}{*}{ Total } \\
\cline { 2 - 4 } & $<3$ & 4 to 6 & 7 to 9 & \\
\hline Arsi & 5 & 3 & 3 & 11 \\
Boran & 5 & 5 & 4 & 14 \\
Harar & 5 & 5 & 4 & 14 \\
Total & 15 & 13 & 11 & 39 \\
\hline
\end{tabular}


for mean separation.

The model used for the analysis was: $Y_{i j k}=\mu+\beta_{1 i}+\beta_{2 j}+\left(\beta_{1} \beta_{2}\right)_{i j}+e_{i j k}$ where,

- $Y_{i j k}=$ the response variables

- $\mu=$ the overall Mean,

- $\beta_{1 \mathrm{i}}=$ the effect of Age,

- $\beta_{2 \mathrm{j}}=$ the effect of breed,

- $\left(\beta_{1} \beta_{2}\right)_{i j}=$ The effect of interaction between age and breed and

- $e_{i j k}=$ Random error

\section{Results and Discussion}

\subsection{Effect of Age and Breeds of Cattle on Carcass and Meat Characteristics}

Breed and age of cattle had significant influence $(P<0.05)$ on live and carcass weights, forequarter and hindquarter weights, and rib eye area (Table 2). Boran

Table 2. Effects cattle of age and breed on carcass characteristics.

\begin{tabular}{|c|c|c|c|c|c|}
\hline \multirow{3}{*}{ Parameters } & \multirow{3}{*}{$\begin{array}{c}\text { Age } \\
\text { (year) }\end{array}$} & \multicolumn{3}{|c|}{ Breeds } & \multirow{3}{*}{$\mathrm{P}$ value } \\
\hline & & Arsi & Boran & Harar & \\
\hline & & Mean \pm SD & Mean \pm SD & Mean \pm SD & \\
\hline \multirow{3}{*}{ Live weight $(\mathrm{kg})$} & $<3$ & $135.20 \pm 13.10^{c}$ & $137.20 \pm 24.26^{\mathrm{c}}$ & $183.60 \pm 44.77^{\mathrm{bc}}$ & NS \\
\hline & $4-6$ & $167.33 \pm 14.64^{\mathrm{bc}}$ & $200.20 \pm 9.65^{b}$ & $181.00 \pm 18.95^{\mathrm{bc}}$ & NS \\
\hline & $7-9$ & $192.00 \pm 9.17^{\mathrm{bc}}$ & $433.00 \pm 39.27^{\mathrm{a}}$ & $155.75 \pm 43.84^{\mathrm{bc}}$ & $* * *$ \\
\hline \multirow{3}{*}{ Carcass weight (kg) } & $<3$ & $69.60 \pm 8.02^{\mathrm{bc}}$ & $57.20 \pm 9.26^{c}$ & $85.00 \pm 19.76^{\mathrm{bc}}$ & NS \\
\hline & $4-6$ & $72.83 \pm 16.51^{\mathrm{bc}}$ & $92.47 \pm 7.21^{\mathrm{b}}$ & $86.80 \pm 12.56^{\mathrm{bc}}$ & NS \\
\hline & $7-9$ & $87.67 \pm 5.13^{b c}$ & $209.73 \pm 11.50^{\mathrm{a}}$ & $72.00 \pm 25.32^{\mathrm{bc}}$ & $* * *$ \\
\hline \multirow{3}{*}{ Dressing percentage (\%) } & $<3$ & $51.60 \pm 5.42$ & $41.80 \pm 1.30$ & $46.40 \pm 1.20$ & NS \\
\hline & $4-6$ & $44.31 \pm 13.60$ & $46.17 \pm 2.43$ & $47.80 \pm 1.93$ & NS \\
\hline & $7-9$ & $45.00 \pm 6.90$ & $48.63 \pm 3.59$ & $45.64 \pm 4.40$ & NS \\
\hline \multirow{3}{*}{ Forequarter (kg) } & $<3$ & $16.56 \pm 2.88^{\mathrm{cd}}$ & $11.79 \pm 5.2^{\mathrm{d}}$ & $15.62 \pm 2.31^{\mathrm{d}}$ & NS \\
\hline & $4-6$ & $19.24 \pm 5.76^{\mathrm{cd}}$ & $33.55 \pm 22.76^{\mathrm{b}}$ & $21.47 \pm 2.83^{\mathrm{cd}}$ & $* * *$ \\
\hline & $7-9$ & $22.69 \pm 0.88^{b c}$ & $56.42 \pm 4.6^{\mathrm{a}}$ & $28.45 \pm 1.44^{\mathrm{bcd}}$ & $* * *$ \\
\hline \multirow{3}{*}{ Hindquarter (kg) } & $<3$ & $16.77 \pm 2.35^{\mathrm{de}}$ & $14.04 \pm 2.73^{\mathrm{e}}$ & $15.64 \pm 1.99^{\mathrm{de}}$ & $* * *$ \\
\hline & $4-6$ & $16.55 \pm 2.94^{\mathrm{de}}$ & $22.12 \pm 3.51^{\mathrm{bc}}$ & $21.21 \pm 23.85^{\mathrm{bc}}$ & $* * *$ \\
\hline & $7-9$ & $18.26 \pm 0.21^{\mathrm{cd}}$ & $45.34 \pm 4.23^{\mathrm{a}}$ & $23.83 \pm 2.1^{\mathrm{b}}$ & $* * *$ \\
\hline \multirow{3}{*}{ Rib Eye Area (SI) } & $<3$ & $7.28 \pm 0.5^{\mathrm{bc}}$ & $4.78 \pm 0.86^{\mathrm{d}}$ & $6.06 \pm 1.63^{\mathrm{cd}}$ & $* * *$ \\
\hline & $4-6$ & $7.53 \pm 0.93^{\mathrm{bc}}$ & $7.38 \pm 1.24^{\mathrm{bc}}$ & $6.84 \pm 1.08^{\mathrm{bc}}$ & NS \\
\hline & $7-9$ & $7.83 \pm 1.27^{\mathrm{b}}$ & $10.25 \pm 1.16^{\mathrm{a}}$ & $7.98 \pm 1.28^{\mathrm{b}}$ & $* * *$ \\
\hline
\end{tabular}

${ }^{\text {abcde }}$ Means bearing different superscripts are significantly different, ${ }^{* * *} \mathrm{p}<0.0001,{ }^{* *} \mathrm{P}<0.01,{ }^{*} \mathrm{P}<0.05, \mathrm{NS}$

$=$ None Significant, $\mathrm{SD}=$ Standard deviation, $\mathrm{SI}=$ Square Inch, $\mathrm{Kg}=$ killo gram. 
between 7 and 9 years of age were higher $(P<0.05)$ both in live and carcass weights than Arsi and Harar cattle breeds. The higher live and carcass weights of Boran breed compared to other breeds in the country were similarly reported by [13]. Higher Boran live and carcass weight might be due to the improvement program practiced for the breed since 1960 [25]. The difference in live and carcass weight of Boran breed over Arsi and Harar cattle breed might be also due to the feeding system on which these breeds were finished, i.e. the Boran was finished in ranch condition while the Arsi and Harar under smallholder feeding regime with grazing and crop residues as a major feed resource. Wheat, barley straw, and maize/sorghum stover were the major sources of crop residues used as feed in the latter breeds as they were managed in mixed crop livestock system. Mean carcass weight of Boran breed between 7 to 9 years in the present study was higher than the average carcass weight of $154 \mathrm{~kg}$ reported by [13] for the same breed slaughtered at export abattoir in Ethiopia. The carcass weights of Arsi and Harar cattle breeds were lower than the carcass weight of cattle (135 kg) slaughtered at local abattoirs in Ethiopia [26].

The dressing percentage of Boran breed in the present study was lower than that reported for the same breed reported by [13] and [25] and for Ogaden cattle [27], which was 56\%. Dressing percentage for Arsi and Harar cattle breeds were comparable with the same parameter reported for cattle slaughtered at local and export abattoirs in Ethiopia, which was 46.78\% [13]. Moreover, the dressing percentage in the present study was comparable to Simmental bulls, Brazil Nellore breed and their crossbred bulls [28] [29] [30] [31] [32].

Despite the significant difference in live and carcass weight, age didn't also influenced $(\mathrm{P}>0.05)$ dressing percentage. This may be due to similar proportions of carcass to live weight ratio across different age groups since carcass dressing percentage is related to body weight [33] [34]. Forequarter mean weight of Boran in age category of $4-6$ years was higher $(\mathrm{P}<0.05)$ than Arsi and Harar. At 7 - 9 years, mean of Forequarter of Boran was higher $(\mathrm{P}<0.05)$ than Arsi and Harar. The result of this study was comparable with the finding of [13] on local Ethiopian cattle breeds that showed mean forequarter of Boran at $4-6$ years similar with Barka (34.28 kg), and Harar at 7 - 9 years with Raya (29.78 kg) breeds. The hindquarter weight of Arsi breed in age categories from 4 - 6 years was relatively lower than their counter part Boran and Harar breeds.

Ribeye area is an objective assessment of muscling and an indicator of total muscle in the carcass or live animal [35] [36]. It is an indicator trait of carcass composition associated with muscularity and yield of high value-added cuts [37] [38]. At 7 - 9 years of age, Boran breed recorded significantly higher $(P<0.05)$ value in mean ribeye area than Arsi and Harar while all cattle breeds (4 - 6 years) had similar $(\mathrm{P}>0.05)$ rib eye area. In all cattle breed rib eye area showed increasing trend across the age category. The trend of rib eye area content in Boran was higher than Arsi and Harar. This implies that Boran carcass has a large proportion of lean muscle. 


\subsection{Effect of Age and Breed of Cattle on Meat Yield Percent/Retailed Meat Yield}

Interaction effect of age and breed on meat yield percent presented in Figure 1. At an early age category ( $<3$ years) meat yield percentage of Arsi, Boran and Harar breeds were 50.86, 30 and 18.72, respectively. The yield percent of Boran was comparable with the finding of [39] who has reported $34 \%$ for small framed, $33 \%$ for medium, and large framed cattle. Greater rate of meat yield percent increment was observed for the Harar cattle breed, which was about 13 times increased by only 2.9 times for Boran cattle while decreased by 0.93 for the Arsi breed as the age advanced from one category to the other; which might be an attribute of the environmental management provided to the breeds or genetic reason. At an interaction point mean meat yield percentage of Arsi and Harar were equal, then after a decrease in Arsi and an increase in Harar up to 9 years.

The liner increment of the meat yields percent of Harar cattle might be due to the fact that Hararge area farmers have unique beef cattle fattening practices. Farmers in Hararghe fatten bulls using maize or sorghum thinning as green forage after using the bulls for draft purpose for a season or two.

In addition, [40] reported that in Hararge farmers utilized Fenugreek flour (Trigonella foenumgraecum), fermented dough or their blend, and yeast (Saccharomyces cerevisiae) for fattening Harar cattle. This was different from the management practice of Arsi bulls which entirely depend on crop residue and grazing and Boran bulls exclusively depend on grazing natural pasture at the ranch. Arsi bulls were used for draft purposes for more numbers of seasons which might be one of the reasons for a decline in meat yield percent at the age advanced in addition to the poor quality feed resource. Boran bulls were managed under ranch on natural pasture which might not provide the animal with enough amount and quality of feed for the breed particularly at the age of the animal advanced.

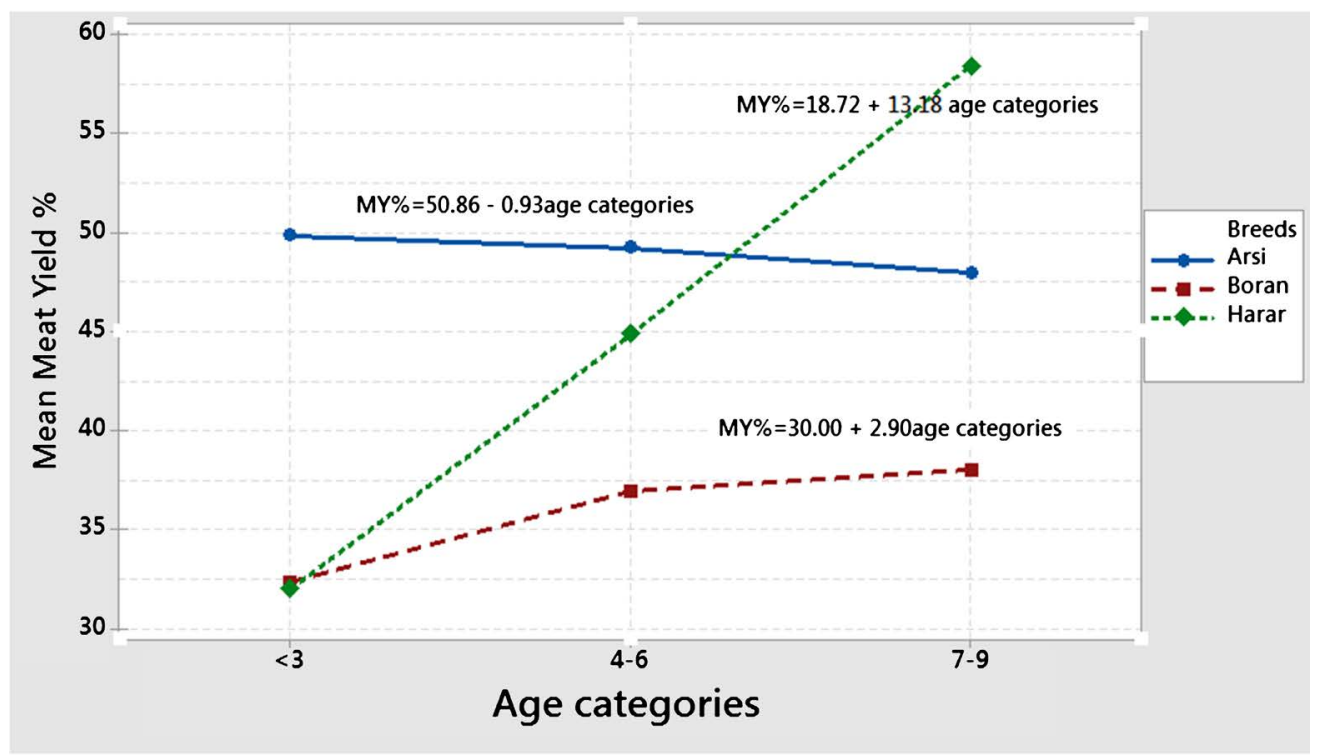

Figure 1. Interaction of age and breed on meat yield percent of Arsi, Boran, and Harar cattle breeds. 


\subsection{Effects of Cattle Age and Breed on Fat Characteristics}

Fat thickness of the three breeds of cattle was in a range of 0.18 to 0.38 inch (Table 3). Higher values of fat thickness as compared to the present finding were recorded for Guzholstein (1.9 inch) and Guzonell (2.6) bulls in Brazil [41]. At 7 9 years fat thickness of Boran cattle breed was significantly greater than that of Arsi. There were no significant difference $(\mathrm{P}>0.05)$ in kidney and pelvic fat content among the breeds across age categories. Weight of heart fat recorded for the three breeds in the current study was less than $(0.86 \pm 0.04)$ that was reported by [42] for the Boran breed slaughtered at 8 years. At age categories from 7 - 9 years, weight of heart and ommental fat were higher $(\mathrm{P}<0.05)$ for Boran than Arsi and Harar cattle breeds.

\subsection{Correlation between Carcass and Meat Characteristics}

Fat thickness was strongly $(\mathrm{P}<0.0001)$ correlated with heart $(\mathrm{r}=0.65)$, and Ommental fats $(r=0.57)$ and carcass weight $(r=0.57)$ (Table 4). The relative proportionality of fat thickness with carcass weight may be due to the slight increment in deposition of fat tissue as cattle advances with age. On the other hand the relative proportions of specific tissues changes as the animal matures, typified by reductions in the growth rates of muscle and bone and increasing rates of

Table 3. Effects of cattle age and breed on fat characteristics.

\begin{tabular}{|c|c|c|c|c|c|}
\hline \multirow{3}{*}{ Parameters } & \multirow{3}{*}{ Age groups } & \multicolumn{3}{|c|}{ Breeds } & \multirow{3}{*}{$\mathrm{P}$-value } \\
\hline & & Arsi & Boran & Harar & \\
\hline & & Mean \pm SD & Mean \pm SD & Mean \pm SD & \\
\hline \multirow{3}{*}{ Fat thickness (inch) } & $<3$ & $0.18 \pm 0.04^{c}$ & $0.18 \pm 0.08^{c}$ & $0.18 \pm 0.04^{c}$ & NS \\
\hline & $4-6$ & $0.2 \pm 0.1^{\mathrm{bc}}$ & $0.28 \pm 0.08^{\mathrm{ab}}$ & $0.2 \pm 0.1^{\mathrm{bc}}$ & NS \\
\hline & $7-9$ & $0.23 \pm 0.06^{b c}$ & $0.38 \pm 0.05^{\mathrm{a}}$ & $0.3 \pm 0.08^{\mathrm{ab}}$ & $* *$ \\
\hline \multirow{3}{*}{ Kidney fat (kg) } & $<3$ & $0.13 \pm 0.02$ & $0.49 \pm 0.79$ & $0.11 \pm 0.04$ & NS \\
\hline & $4-6$ & $0.1 \pm 0.04$ & $0.28 \pm 0.1$ & $0.17 \pm 0.06$ & NS \\
\hline & $7-9$ & $0.16 \pm 0.04$ & $0.58 \pm 0.14$ & $0.56 \pm 0.56$ & NS \\
\hline \multirow{3}{*}{ Pelvic fat (kg) } & $<3$ & $0.14 \pm 0.03$ & $0.14 \pm 0.03$ & $0.3 \pm 0.1$ & NS \\
\hline & $4-6$ & $0.12 \pm 0.02$ & $0.21 \pm 0.08$ & $0.29 \pm 0.13$ & NS \\
\hline & $7-9$ & $0.13 \pm 0.03$ & $0.31 \pm 0.17$ & $0.28 \pm 0.14$ & NS \\
\hline \multirow{3}{*}{ Heart fat (kg) } & $<3$ & $0.16 \pm 0.04^{\mathrm{cd}}$ & $0.14 \pm 0.08^{\mathrm{d}}$ & $0.13 \pm 0.06^{\mathrm{d}}$ & NS \\
\hline & $4-6$ & $0.15 \pm 0.03^{\mathrm{cd}}$ & $0.25 \pm 0.08^{\mathrm{bc}}$ & $0.21 \pm 0.1^{\mathrm{cd}}$ & NS \\
\hline & $7-9$ & $0.19 \pm 0.05^{\mathrm{cd}}$ & $0.58 \pm 0.1^{\mathrm{a}}$ & $0.35 \pm 0.14^{\mathrm{b}}$ & $* * *$ \\
\hline \multirow{3}{*}{ Ommental fat (kg) } & $<3$ & $0.30 \pm 0.16^{\mathrm{cd}}$ & $0.20 \pm 0.01^{\mathrm{d}}$ & $0.29 \pm 0.15^{\mathrm{cd}}$ & NS \\
\hline & $4-6$ & $0.31 \pm 0.18^{\mathrm{cd}}$ & $0.53 \pm 0.30^{b c}$ & $0.67 \pm 0.23^{b}$ & $* * *$ \\
\hline & $7-9$ & $0.43 \pm 0.17^{\mathrm{bcd}}$ & $1.20 \pm 3.40^{\mathrm{a}}$ & $0.73 \pm 0.23^{b}$ & ** \\
\hline
\end{tabular}

${ }^{\mathrm{abcd}}$ Means bearing different superscripts are significantly different, ${ }^{* * *} \mathrm{p}<0.0001,{ }^{* *} \mathrm{P}<0.01,{ }^{*} \mathrm{P}<0.05, \mathrm{NS}=$ Non Significant, $\mathrm{SD}=$ Standard deviation, $\mathrm{In}=$ Inch, $\mathrm{Kg}=$ Killo gram . 
fat deposit [43] [44].

Kidney fat is strongly $(\mathrm{P}<0.0001)$ correlated with ommental fat, while negatively correlated with eye rib area $(\mathrm{p}=0.67)$ and dressing percentage $(\mathrm{P}=0.90)$. Pelvic fat somewhat strongly correlated with Omental fat $(P=0.0019)$, live weight $(P=0.0023)$ and carcass weight $(P=0.005)$. Heart fat, Ommental fat, and live weight have strongly correlated with carcass weight $(\mathrm{P}<0.0001)$. Ommental fat strongly correlated with live weight $(\mathrm{P}=0.0002)$ and carcass weight $(\mathrm{P}<$ 0.0001) Meat Yield was strongly correlated with ommenta fat, live weight and carcass weight and negatively correlated with kidney fat.

\subsection{Effect of Age and Breed of Cattle on Primal Meat Cuts Percentage}

The proportions of the primal meat cuts of the breeds were presented in Table 5. A primal cut is a larger section of a carcass from which retail cuts are made [16].

Table 4. Correlation between carcass and meat characteristics of Arsi, Boran, and Harar cattle breeds.

\begin{tabular}{|c|c|c|c|c|c|c|c|c|c|c|}
\hline & FT & $\mathrm{KF}$ & $\mathrm{PF}$ & $\mathrm{HF}$ & REA & OF & LW & CW & DP & MY \\
\hline FT & 1 & 0.21 (NS) & 0.15 (NS) & $0.65^{\star * *}$ & $0.4(\mathrm{NS})^{\star *}$ & $0.57^{* * *}$ & $0.54^{\star *}$ & $0.57^{* * *}$ & 0.02 (NS) & 0.16 (NS) \\
\hline $\mathrm{KF}$ & & 1 & 0.26 (NS) & $0.34^{* *}$ & -0.08 (NS) & $0.69^{* * *}$ & $0.42^{* *}$ & $0.25(\mathrm{NS})$ & $-0.02(\mathrm{NS})$ & -0.03 (NS) \\
\hline $\mathrm{PF}$ & & & 1 & $0.38^{* *}$ & 0.01 (NS) & $0.48^{* *}$ & $0.47^{* *}$ & $0.43^{* *}$ & 0.18 (NS) & 0.11 (NS) \\
\hline $\mathrm{HF}$ & & & & 1 & $0.4^{\star}$ & $0.54^{\star \star}$ & $0.45^{\star *}$ & $0.77^{\star \star *}$ & $0.11(\mathrm{NS})$ & 0.25 (NS) \\
\hline REA & & & & & 1 & 0.37 (NS) & 0.25 (NS) & 0.28 (NS) & 0.14 (NS) & $0.31(0.05)$ \\
\hline OF & & & & & & 1 & $0.56^{\star * *}$ & $0.76^{* * *}$ & 0.23 (NS) & $0.74^{* * *}$ \\
\hline LW & & & & & & & 1 & $0.98^{* * *}$ & 0.10 (NS) & $0.85^{* * *}$ \\
\hline $\mathrm{CW}$ & & & & & & & & 1 & 0.28 (NS) & $0.87^{\star * *}$ \\
\hline $\mathrm{DP}$ & & & & & & & & & 1 & 0.11 (NS) \\
\hline MY & & & & & & & & & & 1 \\
\hline
\end{tabular}

${ }^{* * *} \mathrm{p}<0.0001,{ }^{* *} \mathrm{P}<0.01,{ }^{*} \mathrm{P}<0.05, \mathrm{NS}=$ Non Significant, FT $=$ Fat Thickness, KF $=$ Kidney Fat, PF $=$ Pelvic Fat, REA = Rib Eye Area, OF $=$ Ommental Fat, LW $=$ Live Weight, $\mathrm{CW}=$ Carcass Weight, $\mathrm{DP}=$ Dressing Percentage, $\mathrm{MY}=$ Meat Yield (meat + fat $)$

Table 5. Proportions of the primal meat cuts of the breeds.

\begin{tabular}{cccc}
\hline \multirow{2}{*}{ Beef Cut } & \multicolumn{3}{c}{ Primal Meat Cut Percentage by Breeds } \\
\cline { 2 - 4 } & Arsi & Boran & Harar \\
\hline Chuck & 31.38 & 31.08 & 32.1 \\
Round & 18.2 & 17.25 & 19 \\
Loin & 19.67 & 19.42 & 18.95 \\
Rib & 8.74 & 9.45 & 7.87 \\
Plate & 2.84 & 2.54 & 3.51 \\
Flank & 1.56 & 1.51 & 1.46 \\
Brisket & 2.49 & 2.45 & 2.06 \\
Shank & 15.12 & 16.3 & 14.99 \\
\hline
\end{tabular}


Because of differences in composition and preference for lean content, wholesale cuts differ in economic value [45] [46]. The effects of age and breed of cattle on primal meat cuts percentage were summarized in Table 6. The chuck, rib, and round primal cuts of Arsi breed accounts $31.38 \%, 7.74 \%$ and $18.2 \%$ of carcass, respectively. The chuck, rib, and round primal cuts of Boran breed accounts $31.08 \%, 9.45 \%$ and $17.25 \%$ of carcass, respectively. The chuck, rib, and round primal cuts of Harar breed accounts $32.1 \%, 7.87 \%$ and $19 \%$ of carcass, respectively. Similar to the present finding, [47] reported primal meat cuts percentages of chuck, rib, and round were $29 \%, 9 \%$, and $22 \%$ of carcass, respectively. On the other hand [48] reported less Chuck (29\%), greater Round (22\%) and almost equal Rib (9\%) of carcass.

Age and breed had significant effect on valuable meat cuts. At the age group of $<3$ chuck was higher $(\mathrm{P}<0.05)$ in Harar than Arsi and Boran. In both $<3$ and 4 - 6 years of bulls age rib cut was significantly lower $(\mathrm{P}<0.05)$ in Harar than Arsi and Boran. At 7 - 9 years rib cut was higher $(\mathrm{P}<0.05)$ in Boran than Arsi and Harar. The current study is in agreement with the finding of [49] who reported relatively similar rib cut percentage (9.24\%) and lower chuck cut (16.67\%). However, [50] reported higher mean rib cut percentage (15.45 \pm 1.60$)$ for Hanwoo cattle breed veal calves.

Cut from short loin of $<3$ year Arsi was higher $(\mathrm{P}<0.05)$ than from Boran and Harar. At age between 7 and 9 years cut from tenderloin was lower $(P<0.05)$ in Boran than Arsi and Harar. This finding was lower than the finding reported by [50] on Hanwoo cattle breed veal calves tenderloin (2.76 \pm 0.01$)$. Boran breed of $<3$ years of age yielded greater $(\mathrm{P}<0.05)$ Top and Bottom sirloin than Arsi and Harar.

\subsection{Effect of Age and Breed of Cattle on Primal Meat Cuts Yield/Weight}

The effects of age and breeds of cattle on primal meat cuts yield were summarized in Table 7. Mean value of each carcass cut weight showed significant difference $(\mathrm{P}<0.05)$ by age category. At age between 7 and 9 years mean yield of chuck cut in Boran was higher $(\mathrm{P}<0.05)$ than Arsi and Harar. The mean rib yield of Boran cut at $7-9$ years was significantly greater than mean yield of Arsi and Harar cattle breeds. At age between 7 and 9 years Boran yielded high $(\mathrm{P}<$ 0.05) weight of short loin, sirloin, top sirloin, and bottom sirloin than Arsi and Harar. The higher yield obtained from Boran might be due to good body conformation at slaughter and also might be due to better feed sources availability during rearing time. In agreement to the current study, [42] reported better performance of Boran breed compared to other indigenous breeds. Mean value of round, brisket, and flank in Boran with age of 7 - 9 years was significantly higher than that of Arsi and Harar breeds.

\subsection{Prediction of Meat Yield}

The prediction of meat yield from live weight, hot carcass weight, ribeye area, 
Table 6. Effect of age and breeds of cattle on primal meat cuts percentage.

\begin{tabular}{|c|c|c|c|c|c|}
\hline \multirow{3}{*}{ Primal Cuts (\%) } & \multirow{3}{*}{ Age groups } & \multicolumn{3}{|c|}{ Breed } & \multirow{3}{*}{ P-value } \\
\hline & & Arsi & Boran & Harar & \\
\hline & & Mean \pm SD & Mean \pm SD & Mean \pm SD & \\
\hline \multirow{3}{*}{ Chuck } & $<3$ & $28.53 \pm 2.18^{\mathrm{de}}$ & $28.24 \pm 3.48^{\mathrm{e}}$ & $31.38 \pm 1.5^{\mathrm{bcd}}$ & $* * *$ \\
\hline & $4-6$ & $32.59 \pm 3.43^{\mathrm{abc}}$ & $30.9 \pm 1.57^{\text {cde }}$ & $31.11 \pm 2.2^{\text {bcde }}$ & NS \\
\hline & $7-9$ & $34.93 \pm 2.16^{\mathrm{a}}$ & $34.85 \pm 2.74^{\mathrm{a}}$ & $34.25 \pm 1.37^{\mathrm{ab}}$ & NS \\
\hline \multirow{3}{*}{ Rib } & $<3$ & $8.69 \pm 0.85^{\mathrm{bc}}$ & $8.62 \pm 0.76^{\mathrm{bc}}$ & $7.08 \pm 1.00^{\mathrm{d}}$ & $* *$ \\
\hline & $4-6$ & $9.57 \pm 1.07^{\mathrm{ab}}$ & $9.51 \pm 0.88^{\mathrm{ab}}$ & $7.88 \pm 0.89^{\mathrm{cd}}$ & $* *$ \\
\hline & $7-9$ & $7.98 \pm 0.7^{\mathrm{bcd}}$ & $10.44 \pm 1.74^{\mathrm{a}}$ & $8.83 \pm 0.95^{\mathrm{bc}}$ & $* *$ \\
\hline \multirow{3}{*}{ Short loin } & $<3$ & $8.24 \pm 0.84$ & $6.54 \pm 0.83$ & $6.77 \pm 0.98$ & NS \\
\hline & $4-6$ & $6.56 \pm 1.19$ & $7.29 \pm 0.79$ & $7.25 \pm 0.55$ & NS \\
\hline & $7-9$ & $7.44 \pm 1.00$ & $8.98 \pm 1.95$ & $7.53 \pm 0.97$ & NS \\
\hline \multirow{3}{*}{ Sirloin } & $<3$ & $5.3 \pm 1.00^{\mathrm{a}}$ & $2.186 \pm 1.11^{\mathrm{d}}$ & $4.77 \pm 0.35^{\mathrm{ab}}$ & $* *$ \\
\hline & $4-6$ & $4.24 \pm 1.08^{\mathrm{abc}}$ & $3.30 \pm 1.8^{\mathrm{bcd}}$ & $4.2 \pm 0.96^{\mathrm{abc}}$ & NS \\
\hline & $7-9$ & $4.48 \pm 0.21^{\mathrm{abc}}$ & $3.64 \pm 0.38^{\mathrm{bcd}}$ & $3.14 \pm 2.02^{\mathrm{cd}}$ & ** \\
\hline \multirow{3}{*}{ Tenderloin } & $<3$ & $2.07 \pm 0.32^{\mathrm{ab}}$ & $1.69 \pm 0.28^{\mathrm{bc}}$ & $2.15 \pm 0.27^{\mathrm{ab}}$ & NS \\
\hline & $4-6$ & $2.18 \pm 0.41^{\mathrm{ab}}$ & $1.72 \pm 0.30^{\mathrm{bc}}$ & $2.37 \pm 0.63^{\mathrm{a}}$ & ** \\
\hline & $7-9$ & $2.2 \pm 0.18^{\mathrm{ab}}$ & $1.42 \pm 0.22^{\mathrm{c}}$ & $2.25 \pm 0.51^{\mathrm{a}}$ & $* *$ \\
\hline \multirow{3}{*}{ Top sirloin } & $<3$ & $3.36 \pm 0.25^{\mathrm{b}}$ & $4.66 \pm 0.30^{\mathrm{a}}$ & $2.81 \mathrm{~b} \pm 0.58^{\mathrm{c}}$ & $* * *$ \\
\hline & $4-6$ & $2.72 \pm 0.83^{\mathrm{bc}}$ & $2.914 \pm 0.70^{\mathrm{bc}}$ & $2.68 b \pm 0.29^{c}$ & NS \\
\hline & $7-9$ & $2.84 \pm 0.32^{b c}$ & $2.63 \pm 0.98^{b c}$ & $2.59 \pm 0.21^{\mathrm{c}}$ & NS \\
\hline \multirow{3}{*}{ Bottom sirloin } & $<3$ & $1.66 \pm 0.19^{\mathrm{d}}$ & $5.18 \pm 1.4^{\mathrm{a}}$ & $2.2 \pm 0.22^{\mathrm{cd}}$ & $* *$ \\
\hline & $4-6$ & $2.69 \pm 1.47^{\mathrm{bcd}}$ & $3.4 \pm 1.63^{\mathrm{bc}}$ & $3.53 \pm 0.68^{\mathrm{b}}$ & NS \\
\hline & $7-9$ & $2.35 \pm 0.9^{\mathrm{bcd}}$ & $2.71 \pm 1.06^{\mathrm{bcd}}$ & $2.42 \pm 0.3^{\mathrm{bcd}}$ & NS \\
\hline \multirow{3}{*}{ Round } & $<3$ & $18.91 \pm 1.28^{\mathrm{ab}}$ & $15.14 \pm 3.76^{c}$ & $19.42 \pm 1.84^{\mathrm{ab}}$ & * \\
\hline & $4-6$ & $18.72 \pm 0.8^{\mathrm{abc}}$ & $20.21 \pm 4.69^{\mathrm{a}}$ & $19.65 \pm 1.05^{\mathrm{ab}}$ & NS \\
\hline & $7-9$ & $16.49 \pm 2.98^{\mathrm{abc}}$ & $16.18 \pm 1.47^{\mathrm{bc}}$ & $17.83 \pm 0.83^{\mathrm{abc}}$ & NS \\
\hline \multirow{3}{*}{ Brisket } & $<3$ & $2.65 \pm 0.79$ & $2.69 \pm 1.14$ & $2.11 \pm 0.61$ & NS \\
\hline & $4-6$ & $2.38 \pm 0.15$ & $2.36 \pm 0.58$ & $2.44 \pm 0.61$ & NS \\
\hline & $7-9$ & $2.35 \pm 0.61$ & $2.25 \pm 0.86$ & $1.52 \pm 0.33$ & NS \\
\hline \multirow{3}{*}{ Plate } & $<3$ & $3.05 \pm 0.47$ & $2.68 \pm 0.72$ & $2.61 \pm 0.16$ & NS \\
\hline & $4-6$ & $2.18 \pm 0.97$ & $2.18 \pm 0.35$ & $3.00 \pm 0.31$ & NS \\
\hline & $7-9$ & $3.14 \pm 0.3$ & $2.81 \pm 0.79$ & $5.29 \pm 5.25$ & NS \\
\hline \multirow{3}{*}{ Flank } & $<3$ & $1.77 \pm 0.25$ & $1.52 \pm 0.75$ & $1.5 \pm 0.31$ & NS \\
\hline & $4-6$ & $1.31 \pm 0.57$ & $1.23 \pm 0.27$ & $1.5 \pm 0.44$ & NS \\
\hline & $7-9$ & $1.47 \pm 0.7$ & $1.84 \pm 0.87$ & $1.38 \pm 0.26^{\mathrm{a}}$ & NS \\
\hline \multirow{3}{*}{ Shank } & $<3$ & $15.76 \pm 1.12^{\mathrm{bc}}$ & $20.85 \pm 4.22^{\mathrm{a}}$ & $17.20 \pm 1.70^{\mathrm{ab}}$ & $* * *$ \\
\hline & $4-6$ & $14.85 \pm 1.52^{\mathrm{bc}}$ & $14.98 \pm 2.84^{b c}$ & $14.40 \pm 1.04^{b c}$ & NS \\
\hline & $7-9$ & $14.33 \pm 0.71^{\mathrm{bc}}$ & $12.25 \pm 1.66^{c}$ & $12.97 \pm 0.92^{\mathrm{bc}}$ & NS \\
\hline
\end{tabular}

${ }_{\text {abcde }}$ Means bearing different superscripts are significantly different, ${ }^{* *} \mathrm{p}<0.0001,{ }^{* *} \mathrm{P}<0.01,{ }^{*} \mathrm{P}<0.05$, NS $=$ Non Significant, $\mathrm{SD}=$ Standard deviation, $\%=$ Percentage. 
Table 7. Effect of age and breeds of cattle on primal meat cuts yield.

\begin{tabular}{|c|c|c|c|c|c|}
\hline \multirow{3}{*}{ Primal Cuts (kg) } & \multirow{3}{*}{ Age groups } & \multicolumn{3}{|c|}{ BreedS } & \multirow{3}{*}{ P-value } \\
\hline & & Arsi & Boran & Harar & \\
\hline & & Mean \pm SD & Mean \pm SD & Mean \pm SD & \\
\hline \multirow{3}{*}{ Chuck } & $<3$ & $9.56 \pm 1.90^{\mathrm{cd}}$ & $8.11 \pm 2.25^{\mathrm{d}}$ & $2.25 \pm 0.60^{\mathrm{cd}}$ & NS \\
\hline & $4-6$ & $11.80 \pm 3.71^{\mathrm{cd}}$ & $14.23 \pm 1.27^{\mathrm{bc}}$ & $3.40 \pm 0.72^{\mathrm{bc}}$ & NS \\
\hline & $7-9$ & $14.31 \pm 0.97^{\mathrm{bc}}$ & $35.68 \pm 4.25^{\mathrm{a}}$ & $4.62 \pm 0.51^{\mathrm{b}}$ & $* * *$ \\
\hline \multirow{3}{*}{ Rib } & $<3$ & $2.86 \pm 0.39^{\mathrm{cd}}$ & $2.47 \pm 0.57^{\mathrm{d}}$ & $7.08 \pm 1.00^{\mathrm{d}}$ & NS \\
\hline & $4-6$ & $3.41 \pm 0.79^{\mathrm{bcd}}$ & $4.40 \pm 0.72^{\mathrm{bc}}$ & $7.88 \pm 0.89^{\mathrm{bcd}}$ & NS \\
\hline & $7-9$ & $3.27 \pm 0.31^{\mathrm{bcd}}$ & $10.63 \pm 1.60^{\mathrm{a}}$ & $8.83 \pm 0.95^{\mathrm{b}}$ & $* * *$ \\
\hline \multirow{3}{*}{ Short loin } & $<3$ & $2.73 \pm 0.49^{b}$ & $1.87 \pm 0.44^{\mathrm{b}}$ & $2.10 \pm 0.32^{\mathrm{b}}$ & NS \\
\hline & $4-6$ & $2.33 \pm 0.59^{b}$ & $3.36 \pm 0.47^{\mathrm{b}}$ & $3.09 \pm 0.29^{b}$ & NS \\
\hline & $7-9$ & $3.05 \pm 0.48^{\mathrm{b}}$ & $9.29 \pm 2.81^{\mathrm{a}}$ & $3.94 \pm 0.56^{\mathrm{b}}$ & $* * *$ \\
\hline \multirow{3}{*}{ Sirloin } & $<3$ & $1.73 \pm 0.22^{\mathrm{b}}$ & $0.61 \pm 0.28^{c}$ & $1.50 \pm 0.29^{\mathrm{b}}$ & $* * *$ \\
\hline & $4-6$ & $1.50 \pm 0.44^{\mathrm{b}}$ & $1.48 \pm 0.77^{\mathrm{b}}$ & $1.82 \pm 0.53^{\mathrm{b}}$ & NS \\
\hline & $7-9$ & $1.84 \pm 0.13^{\mathrm{b}}$ & $3.71 \pm 0.20^{\mathrm{a}}$ & $1.65 \pm 1.06^{\mathrm{b}}$ & NS \\
\hline \multirow{3}{*}{ Tenderloin } & $<3$ & $0.70 \pm 0.19^{\mathrm{cd}}$ & $0.48 \pm 0.13^{\mathrm{d}}$ & $0.67 \pm 0.13^{\mathrm{cd}}$ & NS \\
\hline & $4-6$ & $0.77 \pm 0.20^{\mathrm{bcd}}$ & $0.79 \pm 0.14^{\mathrm{bcd}}$ & $1.00 \pm 0.28^{\mathrm{bc}}$ & NS \\
\hline & $7-9$ & $0.90 \pm 0.87^{\mathrm{bcd}}$ & $1.45 \pm 0.19^{\mathrm{a}}$ & $1.18 \pm 0.2 .8^{\mathrm{ab}}$ & $* * *$ \\
\hline \multirow{3}{*}{ Top sirloin } & $<3$ & $1.12^{\mathrm{b}} \pm 0.12$ & $1.33 \pm 0.28^{\mathrm{b}}$ & $0.89 \pm 0.23^{\mathrm{b}}$ & NS \\
\hline & $4-6$ & $0.96 \pm 0.34^{\mathrm{b}}$ & $1.33 \pm 0.30^{\mathrm{b}}$ & $1.16 \pm 0.24^{\mathrm{b}}$ & NS \\
\hline & $7-9$ & $1.16 \pm 0.15^{\mathrm{b}}$ & $2.66 \pm 0.95^{\mathrm{a}}$ & $1.36 \pm 0.11^{\mathrm{b}}$ & $* * *$ \\
\hline \multirow{3}{*}{ Bottom sirloin } & $<3$ & $0.55 \pm 0.12^{\mathrm{b}}$ & $1.46 \pm 0.40^{\mathrm{b}}$ & $0.68 \pm 0.07^{b}$ & NS \\
\hline & $4-6$ & $0.97 \pm 0.59^{\mathrm{b}}$ & $1.61 \pm 0.87^{\mathrm{ab}}$ & $1.49 \pm 1.19^{\mathrm{b}}$ & NS \\
\hline & $7-9$ & $0.96 \pm 0.34^{\mathrm{b}}$ & $2.75 \pm 1.03^{\mathrm{a}}$ & $1.27 \pm 0.15^{\mathrm{b}}$ & $* * *$ \\
\hline \multirow{3}{*}{ Round } & $<3$ & $6.27 \pm 0.02^{\mathrm{bcd}}$ & $4.37 \pm 1.39^{\mathrm{d}}$ & $6.10 \pm 1.10^{\mathrm{cd}}$ & NS \\
\hline & $4-6$ & $6.67 \pm 0.13^{\mathrm{bcd}}$ & $9.44 \pm 3.11^{\mathrm{b}}$ & $8.44 \pm 1.00^{\mathrm{bc}}$ & NS \\
\hline & $7-9$ & $6.74 \pm 1.10^{\mathrm{bcd}}$ & $16.52 \pm 1.51^{\mathrm{a}}$ & $9.33 \pm 0.53^{\mathrm{bc}}$ & $* * *$ \\
\hline \multirow{3}{*}{ Brisket } & $<3$ & $0.88 \pm 0.31$ & $0.72 \pm 0.20$ & $0.67 \pm 0.24$ & NS \\
\hline & $4-6$ & $0.84 \pm 0.15$ & $1.08 \pm 0.28$ & $1.05 \pm 0.28$ & NS \\
\hline & $7-9$ & $0.97^{\mathrm{b}} \pm 0.28$ & $2.34^{\mathrm{a}} \pm 1.05$ & $0.80^{\mathrm{b}} \pm 0.17$ & $* * *$ \\
\hline \multirow{3}{*}{ Plate } & $<3$ & $0.25 \pm 0.59$ & $0.09 \pm 0.41$ & $0.14 \pm 0.47$ & NS \\
\hline & $4-6$ & $0.45 \pm 0.49$ & $0.15 \pm 0.56$ & $0.21 \pm 0.64$ & NS \\
\hline & $7-9$ & $0.15 \pm 0.61$ & $0.72 \pm 1.94$ & $2.68 \pm 0.72$ & NS \\
\hline \multirow{3}{*}{ Flank } & $<3$ & $0.59 \pm 0.14$ & $0.41 \pm 0.14$ & $0.47 \pm 0.14$ & NS \\
\hline & $4-6$ & $0.49 \pm 0.26$ & $0.56 \pm 0.10$ & $0.64 \pm 0.19$ & NS \\
\hline & $7-9$ & $0.61^{\mathrm{b}} \pm 0.30$ & $1.94^{\mathrm{a}} \pm 1.10$ & $0.72^{\mathrm{b}} \pm 0.13$ & $* * *$ \\
\hline \multirow{3}{*}{ Shank } & $<3$ & $5.20^{\mathrm{b}} \pm 0.67$ & $5.84^{\mathrm{b}} \pm 1.02$ & $5.33^{\mathrm{b}} \pm 0.37$ & NS \\
\hline & $4-6$ & $5.25^{\mathrm{b}} \pm 0.85$ & $6.88^{\mathrm{b}} \pm 1.31$ & $6.13^{\mathrm{b}} \pm 0.51$ & NS \\
\hline & $7-9$ & $5.87^{\mathrm{b}} \pm 0.34$ & $12.54^{\mathrm{a}} \pm 1.85$ & $6.79^{\mathrm{b}} \pm 0.50$ & $* * *$ \\
\hline
\end{tabular}

abcd Means bearing different superscripts are significantly different, ${ }^{* * *} \mathrm{p}<0.0001,{ }^{* *} \mathrm{P}<0.01,{ }^{*} \mathrm{P}<0.05$, NS $=$ Non Significant, SD = Standard deviation, $\mathrm{kg}=$ killo gram. 
Table 8. Prediction of meat yield from live weight, hot carcass weight, rib areas, and primal cuts.

\begin{tabular}{llc}
\hline Equations & $\mathrm{R}^{2}$ & $\mathrm{P}$-value \\
\hline $\mathrm{MY}=5.99+0.1611 \mathrm{Live} w \mathrm{t}$ & $70.66 \%$ & $* * *$ \\
$\mathrm{MY}=7.18+0.3322 \mathrm{HCW}$ & $74.75 \%$ & $* * *$ \\
$\mathrm{MY}=-11.32+0.2434 \mathrm{HCW}+3.693 \mathrm{RA}$ & $84.08 \%$ & $* * *$ \\
$\mathrm{MY}=3.85+1.488 \mathrm{Ch}(\mathrm{kg})+3.03 \mathrm{Sirl}(\mathrm{kg})+7.77 \mathrm{Tenl}(\mathrm{kg})$ & $93.66 \%$ & $* * *$ \\
$\mathrm{MY}=3.39+1.295 \mathrm{Ch}(\mathrm{kg})+4.20 \mathrm{Sirl}(\mathrm{kg})+6.51 \mathrm{Tenl}(\mathrm{kg})+1.721 \mathrm{Plate}(\mathrm{kg})$ & $94.28 \%$ & $* * *$ \\
$\mathrm{MY}=8.27+2.0052 \mathrm{Ch}(\mathrm{kg})$ & $91.97 \%$ & $* * *$ \\
$\mathrm{MY}=11.31+15.18 \mathrm{Sirl}(\mathrm{kg})$ & $66.20 \%$ & $* * *$ \\
$\mathrm{MY}=1.06+42.02 \mathrm{Tenl}(\mathrm{kg})$ & $65.99 \%$ & $* * *$ \\
\hline
\end{tabular}

${ }^{* *} \mathrm{P}<0.0001,{ }^{* *} \mathrm{P}<0.01,{ }^{*} \mathrm{P}<0.05, \mathrm{MY}=$ Meat yield, HCW $=$ Hot carcass weight, $\mathrm{RA}=$ rib area; Live wt $=$ Live weight, $\mathrm{Ch}=$ Chuck, Sirl $=$ Sirloin, Tenl $=$ Tenderloin, $\mathrm{kg}=$ Kilogram.

chuck, sirloin, tenderloin, and plate were summarized in Table 8. Meat yield can be effectively predicted from live weight with coefficient determination $\left(\mathrm{R}^{2}\right)$ of $70.66 \%$. At $74.75 \%$ of coefficient determination meat yield was predicted well from the hot carcass weight. Chuck, sirloin, and tenderloin also effectively predicted meat yield with coefficient determination of $91.97 \%, 66.20 \%$, and $65.99 \%$, respectively. This indicated that the live and hot carcass weight, chuck, sirloin and tenderloin could be reliable measurement in estimation of meat yield.

\section{Conclusion and Recommendation}

From the study, it was concluded that age and breeds of cattle had significantly influence on carcass and meat characteristics. In old age (7 - 9 years) Boran better performed than Arsi and Harar in live weight, carcass weight, forequarter, rib eye area, heart and ommental fat, rib cut percentage, chuck cuts weight and loin weight. Arsi bulls yielded higher meat yield percent at an early age ( $<3$ years), while decreasing as the age advanced and the meat yield percentage from Harar cattle increased linearly as the age advanced up to 9 years. Live and hot carcass weight, chuck, sirloin and tenderloin could be reliable measurement in estimation of meat yield. Therefore, to determine whether variations were due to genetic or environmental cause's evaluation of the three breeds under similar feeding was recommended.

\section{Acknowledgements}

I would like to express my gratitude to USAID and its Feed the Future Innovative Lab for Livestock System managed by the University of Florida and ILRI for funding thus research work. Postgraduate Program Directorate and School of Animal Range Sciences of Haramaya University and Oda Bultum University are highly appreciated for their unreserved cooperation during the study. Ethiopian Science and Higher Education and Ethiopian Agricultural Research Institute for their co-finding the research work. Oromia Pastoral Commission and Didu- 
Tiyura Cattle Ranch for allowing Boran breed. The cooperation obtained from staff members at ELFORA export abattoir of Bishoftu.

\section{Conflicts of Interest}

The authors declare no conflicts of interest regarding the publication of this paper.

\section{References}

[1] CSA Central Statistical Agency (2018) Agricultural Sample Survey Report on Livestock and Livestock Characteristics.

[2] Sintayehu, G., Samuel, A., Baker, D., Ayele, S. and Davies, R. (2013) Study of the Ethiopian Live Cattle and Beef Value Chain. ILRI Discussion Paper 23, International Livestock Research Institute, Nairobi.

[3] Ayele, S., Assegid, W., Jabbar, M.A., Ahmed, M.M. and Belachew, H. (2003) Livestock Marketing in Ethiopia: A Review of Structure, Performance and Development Initiatives. Socio-Economics and Policy Research Working Paper 52, ILRI (International Livestock Research Institute), Nairobi, 35 p.

[4] Arse, G., Mohammed, Y. and Ameha, S. (2013) Evaluation of Eating Qualities of Ethiopian Beef of Arsi Cattle in Adama Town, Oromia, Ethiopia.

[5] FAO (2018) Food and Agricultural Organization of the United Nations. Livestock and Livelihoods Spotlight. Cattle Sector Ethiopia.

[6] IBC (2004) Institute of Biodiversity Conservation. The State of Ethiopia's Farm Animal Genetic Resources: Country Report. A Contribution to the First Report on the State of the World's Animal Genetic Resources. IBC, Addis Ababa.

[7] Mulugeta, F.G. (2015) Production System and Phenotypic Characterization of Begait Cattle, and Effects of Supplementation with Concentrate Feeds on Milk Yield and Composition of Begait Cows in Humera Ranch, Western Tigray, Ethiopia. PhD Dissertation.

[8] Koch, R.M., Dikeman, M.E. and Crouse, J.D. (1982) Characterization of Biological Types of Cattle (Cycle III). III. Carcass Composition, Quality and Palatability. Journal of Animal Science, 54, 35-45. https://doi.org/10.2527/jas1982.54135x

[9] Frylinck, L., Strydom, P.E., Webb, E.C. and du Toit, E. (2013) Effect of South African Beef Production Systems on Post-Mortem Muscle Energy Status and Meat Quality. Meat Science, 93, 827-837. https://doi.org/10.1016/j.meatsci.2012.11.047

[10] Shorthose, W.R. and Harris, P.V. (1990) Effect of Animal Age on the Tenderness of Selected Beef Muscles. Journal of Food Science, 55, 1-8.

https://doi.org/10.1111/j.1365-2621.1990.tb06004.x

[11] Yesihak, M.Y. and Webb, E.C. (2015) Carcass Quality Audit-A Strategy to Improve Beef Sector in Ethiopia. Journal of Agricultural Research, 10, 2731-2737. https://doi.org/10.5897/AJAR2015.9524

[12] Zekarias, B., Shewangizawu, W., Tesfaye, A., Melese, Y., Asrat, T., Berekt, Z. and Deibe, G. (2016) Evaluation of Locally Available Energy Source Feeds on Fattening Performance of Local Oxen and Carcass Analysis in Wolaita, Southern Ethiopia. Hydrology: Current Research, 7, 255. https://doi.org/10.4172/2157-7587.1000255

[13] Yesihak, M.Y. (2015) Beef Carcass Quality, Yield and Causes of Condemnation in Ethiopia. PhD Thesis, University of Pretoria, Pretoria.

[14] Tekalign, K. and Seid, G. (2015) A Review on Compositional Constituents, Quality 
Characteristics and Trace Elements in Beef, Sheep and Goat Meat in Ethiopia.

[15] Timketa, D. and Negassi, A. (2017) Review on Beef Eating Quality Attributes (Tenderness, Juiciness and Flavor) and Quality Standards in Ethiopia. Food Science and Quality Management, 62. http://www.iiste.org

[16] CBB and NCBA (Cattlemen's Beef Board and National Cattlemen's Beef Association) (2009) The Guide to Identifying Meat Cuts.

[17] Pethick, D.W., Ball, A.J., Banks, R.G. and Hocquette, J.F. (2011) Current and Future Issues Facing Red Meat Quality in a Competitive Market and How to Manage Continuous Improvement. Animal Production Science, 51, 13-18. https://doi.org/10.1071/AN10041

[18] Mirzaei, H.R., Verbyla, A.P. and Pitchford, W.S. (2011) Joint Analysis of Beef Growth and Carcass Quality Traits through Calculation of Co-Variance Components and Correlations. Genetics and Molecular Research, 10, 433-447. https://doi.org/10.4238/vol10-1gmr1108

[19] Torrell, R. (1998) Methods of Determining Age in Cattle. Cattle Producer's Library: CL712. University of Nevada, Reno.

[20] MLA Meat and Livestock Australia (2011) Tropical Beef Production Manual. Module 2 Cattle Nutrition for Beef Production.

[21] USDA United States Department of Agriculture (1996) Standards for Grades of Slaughter Cattle and Standards for Grades of Carcass Beef. Agricultural Marketing Services, USDA, Washington DC.

[22] Warriss, P.D. (2000) Meat Science. CABI Publish, New York.

[23] Levy, J. (2008) Meat the Press Mondays: Learn Your Cuts of Steak-The Beef Digarams. Prime Cuts.

[24] SAS (2009) Statistical Analysis Software. Users' Guide Statistics Version 9.1. SAS Institute Inc., Cary.

[25] Aynalem, H., Workneh, A., Noah, K., Tadelle, D. and Azage, T. (2011) Breeding Strategy to Improve Ethiopian Boran Cattle for Meat and Milk Production. Improving Productivity and Market Success of Ethiopian Farmers Project (IPMS), Working Paper No. 26, International Livestock Research Institute (ILRI), Addis Ababa.

[26] Yesihak, M.Y. and Webb, E.C. (2014) Ethiopian Beef Carcass Characteristics. African Journal of Agricultural Research, 9, 3766-3775.

[27] Yoseph, M., Mengistu, U., Mohammed, Y.K. and Merga, B. (2011) Effect of Strategic Supplementation with Different Proportion of Agro-Industrial By-Products and Grass Hay on Body Weight Change and Carcass Characteristics of Tropical Ogaden Bulls (Bos indicus) Grazing Native Pasture. African Journal of Agricultural Research, 6, 825-833.

[28] Ustuner, H., Yalcintan, H., Orman, A., Ardicli, S., Ekiz, B., Gencoglu, H. and Kandazoglu, O. (2017) Effects of Initial Fattening Age on Carcass Characteristics and Meat Quality in Simmental Bulls Imported from Austria to Turkey. South African Journal of Animal Science, 47, 194-201. https://doi.org/10.4314/sajas.v47i2.11

[29] Rotta, P.P., Prado, R.M., Prado, I.N., Valero, M.V., Visentainer, J.V. and Silva, R.R. (2009) The Effects of Genetic Groups, Nutrition, Finishing Systems and Gender of Brazilian Cattle on Carcass Characteristics and Beef Composition and Appearance: A Review. Asian Australasian Journal of Animal Sciences, 22, 1718-1734. https://doi.org/10.5713/ajas.2009.90071

[30] Zawadzki, F., Prado, I.N., Marques, J.A., Zeoula, L.M., Rotta, P.P., Sestari, B.B. and 
Rivaroli, D.C. (2011) Sodium Monensin or Propolis Extract in the Diets of Feedlot-Finished Bulls: Effects on Animal Performance and Carcass Characteristics. Journal of Animal and Feed Sciences, 20, 16-25. https://doi.org/10.22358/jafs/66153/2011

[31] Cruz, O.T.B., Valero, M.V., Zawadzki, F., Rivaroli, D.C., Prado, R.M., Lima, B.S. and Prado, I.N. (2014) Effect of Glycerine and Essential Oils (Anacardium occidentale and Ricinus communis) on Animal Performance, Feed Efficiency and Carcass Characteristics of Crossbred Bulls Finished in a Feedlot System. Italian Journal of Animal Science, 13, 790-797. https://doi.org/10.4081/ijas.2014.3492

[32] Barcellos, V.C., Mottin, C., Passetti, R.A.C., Guerrero, A., Carlos Emanuel Eiras, C.E., Prohman, P.E., Vital, A.C.P. and Ivanor Nunes do Prado, I.N. (2017) Carcass Characteristics and Sensorial Evaluation of Meat from Nellore Steers and Crossbred Angus vs. Nellore Bulls. Animal Science Journal, 39, 437-448.

https://doi.org/10.4025/actascianimsci.v39i4.36692

[33] Macedo, L.M., Prado, I.M., Prado, J.M., Rotta, P., Prado, R.M., Souza, N.E. and Prado, I.N. (2008) Chemical Composition and Fatty Acids Profile of Five Carcass Cuts of Crossbred Heifers Finished in Feedlot. Semina: Ciências Agrárias, 29, 597-608.

[34] Pogorzelska-Przybyłek, P., Nogalski, Z., Sobczuk-Szul, M., Purwin, G. and Kubiak, D. (2018) Carcass Characteristics and Meat Quality of Holstein-Friesian $\times$ Hereford Cattle of Different Sex Categories and Slaughter Ages. Archives Animal Breeding, 61, 253-261. https://doi.org/10.5194/aab-61-253-2018

[35] Greiner, S.P. (2002) Understanding Expected Progeny Differences (EPDs). Publication Number 400-804. Virginia Tech University: Virginia Cooperative Extension, College Town.

[36] Greenfield, J.B. (2009) Carcass Trends in Beef Cattle Shown at the Clarksville Better Beef Show.

[37] Baldassini, W.A., Cahdulo, L.A.L., Silva, J.A.V., et al. (2017) Meat Quality Traits of Nellore Bulls According to Different Degrees of Backfat Thickness: A Multivariate Approach. Animal Production Science, 57, 363-370. https://doi.org/10.1071/AN15120

[38] Aranha, A.S., Andrighetto, C., Lupatini, G.C., Mateus, G.P., Ducatti, C.R., Roça, O., Martins, M.B., Santos, J.A.A., Luz, P.A.C., Utsunomiya, A.T.H. and Athayde, N.B. (2018) Performance, Carcass, and Meat Characteristics of Two Cattle Categories Finished On Pasture during the Dry Season with Supplementation in Different Forage Allowance. Arquivo Brasileiro de Medicina Veterinária e Zootecnia, 70, 517-524. https://doi.org/10.1590/1678-4162-9576

[39] Reiling, B.A., Rouse, G.H. and Duello, D.A. (1992) Predicting Percentage of Retail Yield from Carcass Measurements, the Yield Grading Equation, and Closely Trimmed, Boxed Beef Weights. Journal of Animal Science, 70, 2151-2158. https://doi.org/10.2527/1992.7072151x

[40] Tsigereda, F. and Mengistu, U. (2011) Assessment of Traditional Cattle Fattening Practices and Feedlot Performance of Hararghe Highland Bulls. Review Proceedings 28th Annual Research and Extension, Ethiopia, March 2011, 179-189.

[41] Diniz, F.B., Villela, S.D., Mourthé, M.H., Paulino, P.V., Boari, C.A., Ribeiro, J.S., Barroso, J.A., Pires, A.V. and Martins, P.G. (2016) Evaluation of Carcass Traits and Meat Characteristics of Guzerat-Crossbred Bulls. Meat Science, 112, 58-62.

[42] Mohammed, B. and Hailu, D. (2016) Growth and Slaughter Characteristics of Ethiopian Boran Breed Bull. International Journal of Livestock Research, 6, 41-50. 
https://doi.org/10.5455/ijlr.20150215090156

[43] Berg, R.T. and Butterfield, R.M. (1976) New Concepts of Cattle Growth. Sydney University Press, Sydney, 240 p.

[44] Boito, B., Kuss, F., de Menezes, L.F.G., Lisbinski, E., de Paris, M. and Cullmann, J.R. (2018) Influence of Subcutaneous Fat Thickness on the Carcass Characteristics and Meat Quality of Beef Cattle. Ciência Rural, 48, e20170333.

https://doi.org/10.1590/0103-8478cr20170333

[45] Koch, R.M., Dikeman, M.E. and Cundiff, L.V. (1981) Characterization of Biological Type of Cattle (Cycle II) V. Carcass Wholesale Cuts Composition. Journal of Animal Science, 53, 992-999. https://doi.org/10.2527/jas1981.534992x

[46] Mohammed, A.M. (2004) Effect of Slaughter Weight on Meat Production Potential of Western Sudan Baggara Cattle. PhD Thesis, University of Khartoum, Khartoum.

[47] CBB and NCBA (Cattlemen's Beef Board and National Cattlemen's Beef Association) (2014) Beef Cuts Primal and Sub primal Weights and Yields.

[48] Campbell, J.A. (2016) Understanding Beef Carcass Yields and Losses during Processing.

[49] Hosaina, M.I., Rahmana, M.H., Hossaina, M.M., Akhtera, S., Hashema, M.A., Rahmana, S.M.E. and Deog-Hwan, O. (2015) Effect of Age and Primal Cuts on Beef Quality of Indigenous Cattle.

[50] Yim, D.G., Chung, E.G. and Chung, K.Y. (2015) Meat Quality of Loin and Top Round Muscles from the Hanwoo and Holstein Veal Calves. Korean Journal for Food Science of Animal Resources, 35, 731-737. https://doi.org/10.5851/kosfa.2015.35.6.731 